\title{
PROGRAM GURU AYO MENULIS!!! UPAYA PENINGKATAN KOMPETENSI PROFESIONAL GURU MELALUI PENYUSUNAN INSTRUMEN PENILAIAN AUTENTIK
}

\author{
Muhlis Fajar Wicaksana \\ Program Studi Pendidikan Bahasa dan Sastra Indonesia \\ Fakultas Keguruan dan Ilmu Pendidikan \\ Universitas Veteran Bangun Nusantara Sukoharjo \\ Email: muhlisfajarwicaksana@gmail.com
}

\begin{abstract}
The authentic assessment system in applying the 2013 curriculum is one of the problems faced by Indonesian la nguage teachers in Sukoharjo. Various problems arise in the hope of this a uthentic a ssessment. The purpose of this activity is: 1) fostering the enthu siasm of Indonesian la nguage education teachers to develop their competence in the field of preparing a uthen tic assessment in struments; 2) provide insights into knowledge about developing authentic a ssessment instruments; 3 ) in troduce and a ssist teachers in developing a uthentic assessment instruments. The detailed training is divided in to several a ctivities, namely:(1) Presentation on the authentic assessment sy stem and its characteristics; (2) Discussion of various problems in the application of authentic assessment; (3) assisting the teacher in preparing the assessment instrument for Indonesian subjects. After conducting a series of training, participants learned the importance of developing professional competence of teachers through the preparation of authentic a ssessment instruments. The participants were very enthusiastic about asking questions and discussing after the speakers ga ve their material. Most participants asked about alterna tive solutions to the problems faced in a pplying a uthentic assessment. It is hoped that from the training on the preparation of this authentic assessment instrument, Indonesian language teachers will no longer experience difficulties in preparing the assessmentinstruments.
\end{abstract}

Keywords: teacher competence, authentic assessment, assessmentinstruments

\begin{abstract}
Abstrak. Sistem penilaian autentik pada penerapan kurikulum 2013 menjadisa lah sa tu permasa lahan yang dihadapi oleh guru bahasa Indonesia di Sukoharjo. Berbagai permasalahan muncul pada pena rapan penila ian autentik ini. Tujuan kegiatan ini a dalah 1) menumbuhkan semangat guru pendid ikan bahasa Indonesia untuk mengembangkan kompetensinya dalam bidang penyusunan in strumen penilaian a utentik; 2) memberikan wawasan pengetahuan tentang pengembangan instrumen penilaian autentik; 3 ) mengenalkan dan membantu guru dalam menyu sun instrumen penilaian autentik. Pelaksanaan pelatihan seca ra terperinci dibagi menjadi beberapa kegiatan y aitu:(1) Presentasi tentang sistem penilaian autentik dan karakteristiknya; (2) Diskusi tentang berbagai permasalahan-permasalahan pada penerapan penilaian a utentik; (3) mendampingi guru dalam menyusun instrumen penilaian mata pelajaran bahasa In donesia . Setelah melakukan serangkaian pela tihan, peserta mengetahui artipenting pengemban gan kompetensi profesional guru melalui penyu sunan instrumen penilaian autentik. Pa ra peserta sangat antusias bertanya dan berdiskusi setelah pemateri menyampaikan materinya. Sebagian besar peserta bertanya tentang solusi a lternatif dalam permasalahan yang dihadapai pa da penerapan penila ian a utentik. Dih a rapkan dari pelatihan penyusunan instrumen penilaian autentik ini, guru ba has a Ind one sia tida la gi mengalami kesulitan dalam menyusun in strumen penilaian.
\end{abstract}

Kata kunci: kompetensi guru, penilaian autentik, instrumen penilaian

\section{PENDAHULUAN}

Penilaian merupakan salah satu alat untuk mengambil sebuah keputusan akhir sebagai ukuran tingkat prestasi seseorang. Menurut Kellaghan dan Greaney (2001:19) penilaian diistilahkan dengan assesment. Penilaian merupakan prosedur atau aktivitas yang dirancang untuk mengumpulkan informasi mengenai pengetahuan, sikap, dan keterampilan individu atau kelompok belajar (siswa). Kebaruan dalam sistem penilaian autentik ini adalah salah satunya dapat memberikan informasi yang lengkap kepada Dinas Pendidikan dan Sekolah untuk merumuskan kebijakan yang tepat serta strategi untuk mengefektifkan pelaksanaan penilaian autentik dalam Kurikulum 2013 yang telah ditetapkan pemberlakuannya oleh Kemeterian Pendidikan dan Kebudayaan. 
Penilaian autentik ini hasilnya lebih bisa dipertanggungjawabkan dengan pertimbangan orisinalitas tugas-tugas yang telah dibuat siswa. Naka harapannya, melalui pengabdian kepada masyarakat ini, para guru dapat dengan mudah mengembangkan, menyusun instrumen penilaiannya, ataupun menerapkan di sekolah masing-masing. Bila dibandingkan dengan pendekatan pada penilaian sebelumnya, jauh lebih rinci, tergambar, dan dapat dipertanggungjawabkan orisinalitasnya.

Tujuan adanya kegiatan pengabdian kepada masyarakat melalui kegiatan ayo menulis ini, pada intinya untuk membantu guru-guru di daerah dalam menerapkan penilaian autentik. Sebelum menerapkan penilaian autentik, guruguru harus mengetahui hakikat penilaian autentik itu sendiri. Mulai dari apa itu penilaian autentik? bagaimana menerapkannya? dan bagaimana bentuk instrumen alat untuk evaluasinya? Harapannya, setelah ada kegiatan guru ayo menulis melalui penyusunan instrumen penilaian autentik yang akan digunakan, guru akan merasakan kepercayaan diri yang tinggi ketika berhadapan dengan siswanya.

Seiring diterapkannya kurikulum 2013, sistem penilaian yang diterapkan dalam pembelajaran adalah penilaian autentik. Penilaian autentik ini ialah penilaian yang menekankan pada kemampuan peserta didik untuk mendemonstrasikan pengetahuan yang dimiliki secara nyata dan bermakna. Penilaian ini berbasis pada penampilan siswa yang didasarkan pada pengetahuan dan keterampilan yang dimilikinya. Masing-masing siswa nantinya menunjukkan kemampuannya melalui penampilan atau performa secara maksimal.

Penerapan sisten penilaian autentik di sekolah menengah pertama (SMP) di wilayah sukoharjo, banyak mengalami permasalahan. Mulai dari perencanaan,pelaksanaan, sampai pada pelaporan. Perencanaan penilaian autentik yang terdapat pada rencana pelaksanaan pembelajaran belum dijalankan oleh guru secara maksimal. Guru belum dapat melakukan penilaian autentik sesuai rubrik penilaian yang digunakan. Guru beralasan pada keterabatasan alokasi waktu dalam pembelajaran bahasa Indonesia.
Permasalahan keterbatasan waktu ini senada dengan yang dinyatakan oleh Jurjani (2009:65); Purwandari (2014:41); Maryam (2014:76); Enggarwati (2015:7); Wicaksana, (2019:3) bahwa waktu yang tidak mencukupi menjadi penyebab guru mengalami kesulitan dalam mengimplementasikan penilaian autentik. Komponen/ instrumen pada penilaian yang terlalu banyak, sehingga menghabiskan waktu dalam memilah aspek tersebut. Hal ini yang mengakibatkan pembelajaran dalam satu hari itu tidak semuanya tuntas dilaksanakan.

Permasalahan lain dalam penerapan penilaian autentik berkaitan dengan sarana dan prasarana sekolah. Sarana dan prasarana yang memadai, dapat mendukung kegiatan guru untuk melakukan penilaian melalui memberikan tugastugas yang didukung oleh fasilitas yang ada. Maka dalam hal ini sarana dan prasarana dapat membawa pengaruh terhadap pelaksanaan penilaian autentik. Sarana dan prasarana yang memadai akan memberikan kemudahan bagi para guru untuk memberikan tugas-tugas kepada siswa dan membantu siswa untuk mengerjakan tugas-tugas tersebut. Sekarang ini di sekolah menengah pertama di Sukoharjo dianggap masih kurang memadai sarana dan prasarananya.

Selain itu, permasalahan lain yang dihadapi guru adalah masalah penyusunan instrumen penilaian. Instrumen penilaian yang biasa digunakan oleh guru, biasanya menggunakan instrumen penilaian yang sudah tersedia. Dengan kata lain, guru langsung menggunakan instrumen penilaian dari buku yang sudah ada (buku paket). Guru enggan untuk menyusun sendiri instrumen penilaian yang akan digunakan. Akibatnya jika terdapat kekeliruan komponen penilaian pada instrumen penilaian yang digunakan, maka penilaian yang dilakukann dapat menyebabkan.

Berdasarkan permasalahan-permasalahan yang ditemukan di atas, maka untuk mengatasi permasalahan yang dihadapi oleh guru-guru bahasa Indonesia di wilayah Sukoharjo, maka perlu dilakukan pelatihan-pelatihan melalui pendampingan untuk mengembangkan instrumen penilaian yang akan digunakan. Guru diberikan wawasan dan pengetahuan cara penyusunan instrumen penilaian autentik yang mudah dan efektif jika digunakan. Selain itu, guru-guru 
diajak praktik langsung dalam penyusunan instrumen penilaian. Sehingga melalui penyusunan secara bersma-sama, dan didampingi oleh pakar ahlinya, guru-guru juga dapat mengecek kesiapan instrumen penilaian yang akan digunakan untuk penilaian siswanya. Maka, dalam hal ini pelatihan penyusunan instrumen penilaian autentik materi pelajaran bahasa Indonesia melalui kegiatan pengabdian masyarakat perlu dilakukan.

\section{METODE PELAKSANAAN}

Pelaksanaan kegiatan pelatihan penyusunan instrumen penilaian dilakukan bersama Musyawarah Guru Mata Pelajaran (MGMP) bahasa Indonesia SMP Kabupaten Sukoharjo. Musyawarah Guru Mata Pelajaran (MGMP) bahasa Indonesia SMP Kabupaten Sukoharjo terdiri atas empat rayon. Setiap rayon terdiri atas tiga kecamatan. Adapun pembagian rayon dapat dilihat sebagai berikut.

Tabel 1. Pembagian Rayon MGMP SMP di Sukoharjo

\begin{tabular}{ll}
\hline \multicolumn{1}{c}{ Rayon } & \multicolumn{1}{c}{ Kecamatan } \\
\hline Rayon 1 & Kecamatan Sukoharjo, Grogol, dan Nguter \\
\hline Rayon 2 & Kecamatan Kartasura, Gatak, dan Baki \\
\hline Rayon 3 & Kecamatan Tawangsari, Bulu, dan Weru \\
\hline Rayon 4 & Kecamatan Bendosari, Mojolaban, dan Polokarto
\end{tabular}

Dalam pengabdian masyarakat ini, pelaksanaan kegiatan pelatihan dilakukan pada rayon 1, yang meliputi: Kecamatan Sukoharjo, Grogol, dan Nguter. Hal ini dilakukan karena pertimbangan keterbatasan waktu dalam pengabdian masyarakat. Pelatihan dilakukan setiap hari sabtu, setelah pembelajaran di sekolah berakhir. Dimulai dari sabtu minggu kedua, ketiga, dan keempat. Setiap pertemuan ditempuh dalam waktu kurang lebih tiga jam atau 180 menit per pertemuan kegiatan pelatihan.

Metode pelaksanaan pengabdian masyarakat ini dilakukan melalui pelatihan, diskusi, dan pendampingan guru. Pelaksanaan pelatihan dimulai dengan presentasi tentang sistem penilaian autentik dan karakteristiknya. Konsep penilaian autentik, tujuan, karakteristik, dan sisi kelemahan serta kelebihan sistem penilaian autentik disampaikan.

Selanjutnya, kegiatan pelatihan yang kedua dilanjutkan dengan diskusi tentang berbagai permasalahan-permasalahan pada penerapan penilaian autentik. Disini guru-guru mengungkapkan berbagai pertanyaan dan tanggapan mengenai sistem penilaian autentik yang sudah diterapkan di kelas. Mulai dari perencanaan, pelaksanaan, sampai sistem pelaporan yang sebagian besar guru sampaikan.

Pelaksanaan kegiatan pelatihan yang terakhir, dilakukan dengan mendampingi guru menyusun instrumen penilaian. pemateri mendampingi guru dalam menyusun instrumen penilaian mata pelajaran bahasa Indonesia. Permasalahan-permasalahan dalam penyusunan instrumen penilaian diungkapkan oleh guru-guru. Disinilah peran pendamping memberikan solusi, menuntun, menguraikan, dan menjelaskan bagaimana mengatasi masalah penyusunan instrumen penilaian tersebut. Adapun jadwal pelaksanaan kegiatan pelatihan penyusunan instrumen penilaian autentik dapat dilihat sebagai berikut:

Tabel 2. Pelaksanaan Pelatihan Penyusunan Instrumen Penilaian Autentik

\begin{tabular}{llll}
\hline No. & \multicolumn{1}{c}{ Kegiatan dan Materi } & $\begin{array}{c}\text { Hari/ Tanggal } \\
\text { Pelaksanaan }\end{array}$ & $\begin{array}{c}\text { Waktu } \\
\text { Pelaksanaan }\end{array}$ \\
\hline 1. & Pelatihan & Sabtu/ 12 September 2020 & Pukul 11.00- \\
& Meliputi: & & 14.00 \\
& $\begin{array}{l} \\
\text { a. Presentasi tentang sistem penilaian } \\
\text { autentik dan karakteristiknya }\end{array}$ & \\
& b. Konsep penilaian autentik, tujuan, \\
& karakteristik, dan sisi kelemahan serta \\
& kelebihan sistem penilaian autentik & & \\
\hline
\end{tabular}




\begin{tabular}{|c|c|c|c|c|}
\hline \multicolumn{5}{|c|}{ disampaikan } \\
\hline 2. & $\begin{array}{l}\text { Diskusi } \\
\text { Meliputi: } \\
\text { a. Diskusi permasalahan-permasalahan pada } \\
\text { penerapan penilaian autentik } \\
\text { b. Penyampaian perencanaan, pelaksanaan, } \\
\text { sampai sistem pelaporan oleh guru }\end{array}$ & Sabtu/ 19 September 2020 & $\begin{array}{l}\text { Pukul } \\
14.00\end{array}$ & $11.00-$ \\
\hline 3. & $\begin{array}{l}\text { Pendampingan guru } \\
\text { Meliputi: } \\
\text { a. Mendampingi guru dalam memberikan } \\
\text { solusi, menuntun, menguraikan, dan } \\
\text { menjelaskan bagaimana mengatasi } \\
\text { masalah penyusunan instrumen penilaian }\end{array}$ & Sabtu/26 September 2020 & $\begin{array}{l}\text { Pukul } \\
14.00\end{array}$ & $11.00-$ \\
\hline
\end{tabular}

Indikator pencapaian dalam program guru ayo menulis ini dailihat dari berbagai sikap dan kompetensi yang dimiliki oleh guru-guru di Sukoharjo. Melalui tes awal (sebelum pelatihan) mengalami kemajuan setelah mengikuti pelatihan dibuktikan dari hasil tes yang meningkat. Dilihat dari sikap guru-guru, pada setiap pertemuan menunjukkan sikap yang positif. Guru-guru yang mengikuti pelatihan muncul rasa kepercayaan diri dalam mengembangkan instrumen penilaian yang akan digunakan. Pola pikir yang berpandangan luas juga sudah mulai dikembangkan pada diri guru-gur semua yang mengikuti pelatihan. Hal ini ditandai melalui aktivnya dsikusi pada setia pertemuan. Semuanya saling memberikan saran dan masukan saling bergiliran.

\section{HASIL DAN PEMBAHASAN}

Evaluasi Keberhasilan dan pelaksanaan program pengabdian masyarakat ini dilihat dari dua tolok ukur sebagai beriku: 1) Respons positif dari peserta pelatihan; dan 2) meningkatnya keterampilan peserta setelah mendapatkan pelatihan. Adapun urainnya sebagai berikut.

\section{Respons Positif dari Peserta Pelatihan}

Respons peserta pelatihan akan diukur melalui observasi selama pelatihan berlangsung dan dengan memberikan kuesioner yang menyangkut kesan, saran, kritik dan usulan peserta pelatihan terhadap program pengabdian masyarakat ini. berdasarkan pelaksanaan kegiatan pelatihan, para guru MGMP bahasa Indonesia SMP terlihat sangat antusias mengikuti. Begitu pemateri menyampaikan materi, para guru dengan suasan a kondusif memperhatikan dengan sungguhsungguh. Hal ini seperti terlihat pada dokumentasi dibawah ini.

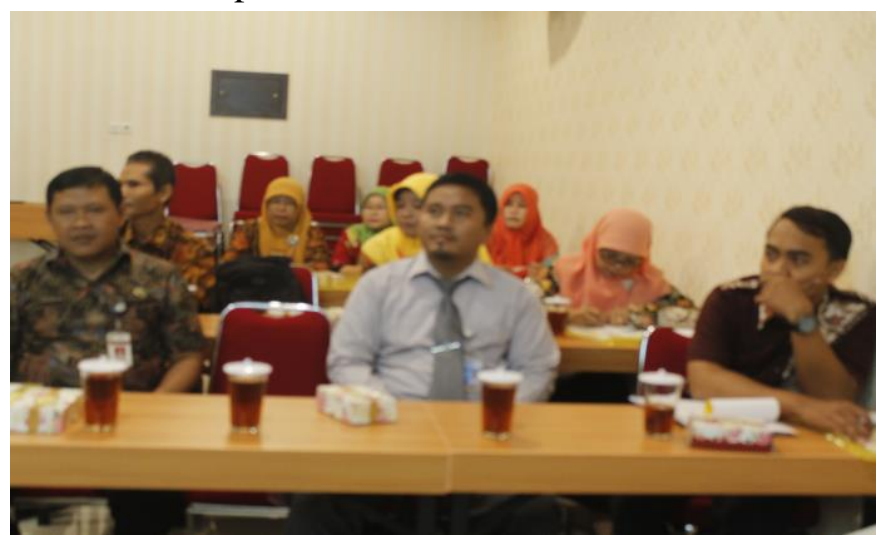

\section{Gambar 1. Guru Antusias Memperhatikan Materi}

Selain keseriusan guru dalam menerima materi pelatihan penyusunan instrumen penilai an autentik bahasa Indonesia, guru juga terlihat aktif memberikan pertanyaan-pertanyaan dan tanggapan dalam pelaksanaan kegiatan pelatihan. Keaktifan ini membuat suasana pelatihan menjadi menyenangkan dan menarik untuk terus diikuti sampai selesai. Guru-guru merasa ada yang kurang jika tidak diikuti sampai selesai. Hal ini terlihat dari dokumentasi-dokumentasi dibawah ini. 


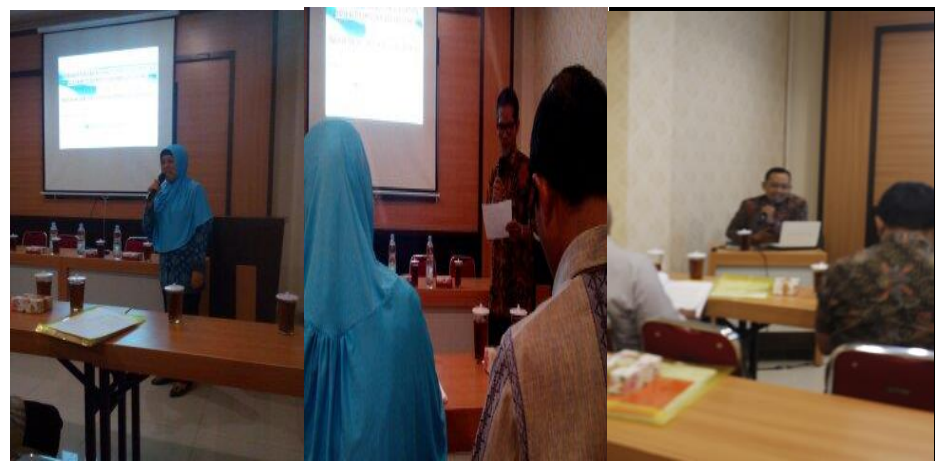

Gambar 2. Guru Aktif Memberikan Pertanyaan dan Tanggapan

Berdasarkan gambar 2 di atas, terlihat seorang guru perempuan dari SMP N 1 Sukoharjo sedang memberikan tanggapannya atas materi penilaian autentik yang telah diberikan. Guru ini bertanya bagaimanakah langkah-langkah yang mudah dalam menyusun instrumen penilaian autentik? Selain itu, guru dari SMP 4 Sukoharjo, yang bernama bapak Suwarji, memberikan beberapa pertanyaan dan tanggapan terkait materi sistem penilaian autentik. Bagaimanakah solusi kerumitan sistem penilaian autentik? Bagaimanakah solusi jalan tengahnya supaya guru juga tidak terlalu rumit dalam melakukan penilaian? pada gambar yang terakhir, pemateri memberikan tanggapan dan beberapa solusi alternatif untuk melakukan penilaian autentik.

\section{Meningkatnya Keterampilan Peserta Setelah Mendapatkan Pelatihan}

Setelah mendapatkan pelatihan penyusunan instrumen penilaian, kemampuan dan keterampilan guru dalam mempersiapkan penilaian autentik di kelas mengalami peningkatan. Berdasarkan pengisian kuesioner yang dibagikan, dari 15 guru yang mengikuti pelatihan, 14 diantaranya tidak mengalami kesulitan lagi dalam menyususn instrumen penilaian. sisanya,satu guru menyatakan perlu ada pelatihan tambahan lagi. Satu guru ini berarti belum begitu percaya diri dengan apa yang didapatkan dari pelatihan. Dapat ditarik simpulan bahwa tingkat keberhasilan pelatihan dapat meningkatkan kemampuan penyusunan instrumen penilaian bagi guru-guru bahasa Indonesia di Sukoharjo.

Kebiasaan guru pada umumnya melakukan penilaian di akhir pembelajaran. Padahal peilaian autentik ini bisa juga dilakukan pada saat proses pembelajaran. Hal ini seenada dengan hasil penelitian Gulikers (2006) menyatakan penilaian Autentik adalah proses yang sedang berlangsung atau berkelanjutan. Oleh karena itu, penilaian autentik ini harus dilakukan secara bersamaan ketika proses pembelajaran berlangsung. Demikian pula untuk penilaian berbasis kompetensi autentik, berkelanjutan, dan individual. Penilaian sebagai proses penilaian kinerja yang multidimensi terhadap perilaku dalam situasi nyata (perilaku kinerja seperti kehidupan sehari-hari).

Selain itu, guru juga harus lebih memperhatikan sistem perencanaan, pelaksanaan, dan penilaian. dalam mengatasi berbagai kendala sistem penilaian autentik, guru harus benar-benar tiga hal tersebut. Sepertihalnya hasil penelitian yang dilakukan oleh Sintadewi, Sriasih, \& Sudiana (2017), terdapat tiga solusi guru dalam mengatasi kendala penilaian keterampilan berbicara yaitu, (1) memberikan kesempatan siswa untuk menyiapkan diri dari jauh hari agar penampilan memuaskan, (2) membuat perencanaan yang sitematis dan belajar bersama dengan guru lainnya, (3) memberikan teknis atau prosedur dalam menghadapi tes berbicara. Hal inilah yang benar-benar diperhatikan oleh guruguru dalam penerapan penilaian autentik.

\section{SIMPULAN DAN SARAN SIMPULAN}

Kegiatan selama pelaksanaan program pelatihan penilaian autentik ini, mulai dari tahap persiapan sampai pelaksanaan, dapat kami sampaikan temuan-temuan bahwa antusiasme guru-guru peserta pelatihan sangat tinggi, para guru menyambut dengan baik tawaran kerjasama 
sebagai mitra dalam program pengabdian masyarakat ini. Pihak sekolah berharap program ini bisa dilaksanakan secara reguler dan berkala di tahun-tahun selanjutnya. Sikap positif ditunjukkan oleh guru-guru musyawarah mata pelajaran (MGMP) bahasa Indonesia, mulai dari keseriusan guru dalam memperhatikan materi, sangat antusias dalam memberikan pertanyaan dan bediskusi dalam pelatihan, serta memberikan saran yang positif untuk menunjang kegiatankegiatan berikutnya.

Selain itu, guru-guru musyawarah mata pelajaran (MGMP) bahasa Indonesia menilai materi pelatihan penyusunan instrumen penilaian autentik di SMP yang diberikan sangat sesuai. Setelah pelatihan dilaksanakan, guru-guru mulai aktif dan berani untuk memodifikasi instrumen penilaian yang sudah tersedia di buku paket. Instrumen penilaian disesuaikan dengan kebutuhan dan kompetensi siswa. Serta instrumen penilaian lebih disederhanakan menjadi instrumen yang tidak terlalu rumit dalam sistem pelaporannya.

\section{SARAN}

Sesuai dengan hasil evaluasi kegiatan pelatihan penyusunan instrumen penilaian autentik guru-guru musyawarah mata pelajaran (MGMP) bahasa Indonesia di Sukoharjo, guru menyarankan untuk program-program pengabdian masyarakat seperti ini bisa dilaksanakan secara reguler dan berkala. Sistem penilaian autentik ini sangat dibutuhkan oleh guru-guru musyawarah mata pelajaran (MGMP) bahasa Indonesia di Sukoharjo. Dari hasil pelatihan penyusunan instrumen penilaian autentik ini guru merasa terbantukan dalam mengatasi berbagai permasalahan-permasalahan yang dihadapai ketika penerapan penilaian autentik di sekolah. Harapannya, pelatihan semacam ini dapat dilakukan lagi dalam waktu lain.

Selain itu, guru-guru musyawarah mata pelajaran (MGMP) bahasa Indonesia di Sukoharjo juga berharap kegiatan pelatihan nantinya tidak hanya terbatas pada penyusunan instrumen penilaian autentik. Bisa dikembangkan untuk kegiatan-kegiatan yang menunjang peningkatan kompetensi guru pada umumnya. Sebagai contoh, pelatihan penyusunan media pembelajaran, penyusunan menulis karya ilmiah, menulis artikel ilmiah dalam jurnal, dan pelatihan penyusunan bahan ajar.

\section{DAFTAR PUSTAKA}

Greaney, Vincent and Thomas Kellaghan. 2001. Assessing National Achievement Levels in Education. Washington, DC: The Worl Bank.

Gulikers. 2006. Authentic Assessment, Student and Teacher Perceptions: The Practical Value of The Five-Dimensional Framework. Journal of Vocational Education and Training. 58: 337-357.

Jurjani, Muhammad. 2009. Keterlaksanaan Penilaian Autentik (Authentic Assessment pada Mata Pelajaran IPA Biologi di kelas VII MTsN Sleman Kota. Yogyakarta: Universitas Islam Negeri Yogyakarta Sunan Kalijaga.

Maryam, Siti. 2014. Penerapan Penilaian Otentik dalam Pembelajaran Bahasa Indonesia (skripsi tidak dipublikasikan) Universitas Negeri Yogyakarta.

Purwandari, Apriliana. 2014. Penilaian Autentik pada Mata Pelajaran Matematika Kurikulum 2013 Guru kelas IV Kota Semarang. Jurnal Pendidikan Matematika, 4 (2), 41.

Sintadewi, Ni Gusti Ayu, Sriasih, Sang Ayu Putu, dan Sudiana, Nyoman. 2017. Teknik Penilaian Keterampilan Berbicara dalam Pembelajaran Bahasa Indonesia di SMA Negeri 4 Denpasar. eJournalPendidikanBahasadanSastraIndo nesia. Volume:

Vol:7No:2Tahun:2017.https://ejournal.un diksha.ac.id/index.php/JJPBS/article/vie w/12001.

Wicaksana, Fajar Muhlis, Suwandi Sarwiji, Winarni Retno, dan Ngadiso. 2019. The Problems in Applying Authentic Assessment for Speaking Skills in Junior High School. Indonesian LanguageEducationandLiterature.eISSN:2502-2261

http://www.syekhnurjati.ac.id/jurnal/inde x.php/jeill/.Vol. 4, No. 2, Juli 2019, 226 239. 